\title{
Respon bawang putih tunggal (Allium sativum L.) pada aplikasi lama induksi siplo dan urine kelinci
}

\author{
Sugiarto ${ }^{1}$, dan Sunawan ${ }^{2}$ \\ 1,2Departemen Agroteknologi, Fakultas Pertanian, Universitas Islam Malang \\ JI. MT. Haryono No. 193 Malang 65144, Jawa Timur, Indonesia \\ Email korespondensi : sugiartounisma9@gmail.com
}

\begin{abstract}
Abstrak
Bawang putih tunggal (Allium sativum L.) relatif mempunyai kualitas kandungan gizi lebih baik dari pada bawang yang berumbi majemuk. Peningkatan kualitas hasil bawang putih tunggal dapat dilakukan dengan perbaikan teknik budidaya. Salah satu alternatif yang bisa diterapkan adalah dengan penerapan Teknologi SIPLO (Sistem Intensifikasi Potensi Lokal). Teknik SIPLO dapat memperbaiki sifat fisik, kimia dan biologi dalam tanah. Cara induksi yang diterapkan pada lahan pertanian akan meningkatkan pertukaran ion dan kation dalam tanah. Tujuan: Meningkatkan kualitas hasil tanaman bawang putih tunggal. Penelitian ini menggunakan metode rancangan acak kelompok faktorial. Faktor I : Lama waktu induksi SIPLO (I 0 : 0 menit, $\mathrm{I}_{1}: 20$ menit, $\mathrm{I}_{2}: 40$ menit , $\mathrm{I}_{3}: 60$ menit). Faktor II : Konsentrasi Urine kelinci $\left(\mathrm{U}_{0}: 0 \mathrm{ml} / \mathrm{L}, \mathrm{U}_{1}: 50 \mathrm{ml} / \mathrm{L}\right.$, $\left.\mathrm{U}_{2}: 100 \mathrm{ml} / \mathrm{L}, \mathrm{U}_{3}: 150 \mathrm{ml} / \mathrm{L}\right)$. Secara umum perlakuan induksi listrik yang diberikan memberikan hasil yang baik. Hasil tanaman bawang putih yang tanpa perlakuan = 5,80 ton/ha (kontrol) dan perlakuan lama Induksi 60 menit dan urine kelinci $150 \mathrm{ml} / \mathrm{L}$ $\left(\mathrm{I}_{3} \mathrm{U}_{3}\right) 8,81$ ton/ha dengan prosentase peningkatan $51.80 \%$.

Kata kunci : Bawang Tunggal, Induksi SIPLO, Urine
\end{abstract}

\begin{abstract}
Onions single (Allium sativum. L) relatively possess better qualities of nutritional content compared to bulbous garlic. Improving the quality and quantity of single garlic can be done through the improvement of cultivation. intensification of local potential systems techniques is a novel technology using electricity induction to improve physical chemical and biological properties in the soil. The electricity induction applied into the soil would increase ion and cation exchange in the ground. The purpose of this study was Improve the quality and quantity production of single garlic. The research used Randomized block design with two factors. Factors I: Time induction ( $\mathrm{I}_{0}$ : 0 minutes, $I_{1}: 20$, minutes $I_{2}: 40$, minutes $I_{3}: 60$ minutes). Factors II: Urine rabbits concentration $\left(U_{0}: 0 \mathrm{ml} / \mathrm{l}, \mathrm{U}_{1}: 50 \mathrm{ml} / \mathrm{l}, \mathrm{U}_{2}: 100 \mathrm{ml} / \mathrm{l}, \mathrm{U}_{3}: 150 \mathrm{ml} / \mathrm{l}\right.$. The result showed a good impact of the application to the production. The application of 60 minutes electricity induction increased the production aroung $51.80 \%$.
\end{abstract}

Keywords: single onions, induction siplo, urine

\section{Pendahuluan}

Kebutuhan bawang putih tunggal (Allium sativum L.) atau (Solo Garlic) semakin meningkat. Harga jual dipasaran relatif lebih mahal jika dibandingkan dengan hasil bawang putih majemuk (umbi banyak). Persoalannya jumlah petani yang menanam bawang putih tunggal sangat sedikit. Keadaan ini perlu dorongan perbaikan dari segi peningkatan hasil, kualitas hasil dan pemasaran.

Produksi tanaman bawang putih tunggal masih relatif sangat rendah. Keadaan ini dikarenakan penurunan kesuburan lahan pertanian. Kegiatan pembangunan pertanian 
yang dicanangkan dengan bentuk pertanian intensif, ternyata menyisakan berbagai persoalan yang kompleks. Penurunan kualitas lahan pertanian antara lain: 1). Produktivitas semakin rendah disebabkan daya dukung lahan kandungan bahan organiknya rendah, potensi mikroorganisme, predator, serangga, sumberdaya air tidak berfungsi sempurna; 2). Biaya operasional budidaya semakin mahal; 3). Potensi lokal belum dimanfaatkan secara optimal untuk perbaikan lingkungan. Kebijakan sistem pertanian konvensional dengan pemakaian pupuk kimia dan pestisida berlebihan terbukti mengakibatkan dampak negatif pada lahan pertanian (Kleijn et al., 2009; Geiger et al., 2010).

Degradasi agroekosistem semakin mendorong terjadinya penurunan kualitas tanah. Lahan pertanian semakin tidak subur. Hal ini terjadi karena pemakaian lahan yang kurang bijak dan pengelolaan tidak maksimal. Pengelolaan lahan dapat juga dilakukan dengan memperbaiki teknik budidaya agar potensi lokal dapat dioptimalisasikan.Perbaikan teknik budidaya bawang putih tunggal dapat dilakukan dengan menerapkan teknologi SIPLO. Teknik SIPLO (Sistem Intensifikasi Potensi Lokal) merupakan sistem terpadu dengan optimalisisasi fungsi seluruh potensi lokal yang ada di lahan pertanian. Potensi lahan hendaknya bisa dimanfaatkan secara baik agar berdaya guna untuk pertumbuhan tanaman. Implementasi teknologi SIPLO pada lahan pertanian didukung dengan alat induksi, yaitu untuk menguraikan senyawa kompleks dan pertukaran kation dalam tanah. Proses elektrifikasi harus dilakukan pada kondisi lahan basah karena air berfungsi sebagai konduktor dalam aliran arus listrik. Aliran listrik yang salurkan dari alat induksi SIPLO akan melepas unsur hara yang terjerap dan terjadi pertukaran kation secara cepat. Pemasangan elektrode di lahan pertanian pada waktu proses induksi berlangsung terjadi pelepasan ion positif dan negatif yang ada di dalam tanah. Dua kutub elektroda (anoda dan katoda) kemudian dialiri arus listrik, sehingga terjadi proses elektrolisis yaitu Anoda : $2 \mathrm{H}_{2} \mathrm{O}-$ $4 \mathrm{e}^{-} \rightarrow \mathrm{O}_{2}+4 \mathrm{H}^{+}$dan Katoda: $2 \mathrm{H}_{2} \mathrm{O}+2 \mathrm{e}^{-} \rightarrow \mathrm{H}_{2}+2 \mathrm{OH}^{-}$. Selama proses electrocuting berjalan terjadi perpindahan ion hidrogen ke kutub katoda dan $\mathrm{OH}^{-}$anoda (electromigration). Keadaan ini diikuti peralihan air pori tanah di area anoda mengarah ke katoda (electroosmosis). Aliran air di dalam pori tanah berfungsi pada kenaikan $\mathrm{OH}^{-}$di area kutub anoda (Shang dan Masterson, 2000).

Peningkatan kualitas hasil bawang putih tunggal sangat membutuhkan ketersediaan hara dan zat pengatur tumbuh selama pertumbuhan. Pemenuhan kebutuhan nutrisi tanaman dapat dibantu dengan pemberian urine hewan. Pupuk cair urine lebih efisien jika pupuk diberikan lewat daun sesuai kebutuhan. Pupuk akan 
efektif untuk tanaman sayuran jika jumlah dan konsentrasinya sesuai dengan kebutuhan. Penelitian ini bertujuan untuk meningkatan hasil dan kualitas bawang putih tunggal melalui perlakuan induksi listrik dan aplikasi urine kelinci.

\section{Bahan dan Metode}

Pelaksanaan penelitian Juni 2019 di Karangploso, Malang. Ketinggian tempat 665 mdpl, suhu rata - rata $24^{\circ} \mathrm{C}$, curah hujan 2000-3000/tahun, kelembaban $80 \%$. Jenis tanah tempat penelitian adalah aluvial. Peralatan menggunakan alat induksi SIPLO, Aki, Avometer, kawat email, pH meter, refraktometer, spektofotometer, urine kelinci, benih bawang putih tunggal. Metode memakai rancangan acak kelompok faktorial. Faktor I : yaitu lama waktu induksi; ( $I_{0}: 0$ menit, $\mathrm{I}_{1}: 20$ menit, $\mathrm{I}_{2}: 40$ menit, dan $\mathrm{I}_{3}: 60$ menit). Faktor II: yaitu pupuk cair urine kelinci; $\left(\mathrm{U}_{0}: 0 \mathrm{ml} / \mathrm{L}, \mathrm{U}_{1}: 50 \mathrm{ml} / \mathrm{L}, \mathrm{U}_{2}: 100 \mathrm{ml} / \mathrm{L}\right.$, dan $U_{3}: 150 \mathrm{ml} / \mathrm{L}$ ). Parameter pengamatan yaitu kandungan klorofil daun dan peningkatan hasil bawang putih tunggal. Analisis menggunakan uji anova $F 5 \%$, dan uji regresi.

\section{Hasil dan Pembahasan}

Peningkatan hasil tanaman bawang putih tunggal (Solo Garlic) yang ditanam pada dataran medium menunjukkan respon pertumbuhan sebagaimana tersaji pada Tabel 1. Kombinasi lama induksi dan pemberian urine kelinci memperlihatkan pengaruh dan berbeda nyata pada peningkatan hasil, jika dibandingkan dengan kontrol. Tanaman bawang putih tunggal yang menghendaki persyaratan tumbuh pada daerah dataran tinggi masih menunjukkan hasil relatif tinggi. Tanaman bawang putih tunggal memperlihatkan pertumbuhan yang normal dan hasil umbi baik. Keadaan ini dipengaruhi oleh ketersediaan hara yang ada didalam tanah maupun supai hara langsung melalui daun. Kebutuhan nutrisi yang tercukupi akan mendorong tanaman menghasilkan fotosintat yang dialokasikan ke bagian umbi cukup banyak.

Perlakuan lama Induksi SIPLO 60 menit dan pemberian Urine kelinci $150 \mathrm{ml} / \mathrm{L}$ $\left(\mathrm{I}_{3} \mathrm{U}_{3}\right)$ menunjukkan ada perbedaan nyata pada peningkatan produksi bawang putih tunggal yaitu 8.81 ton/ha dengan peningkatan sebesar 51,8 \%. Peningkatan produksi bawang putih tunggal diakibatkan adanya pemberian aliran listrik pada lahan. 
Tabel 1. Rata hasil bawang putih tunggal pada kombinasi lama induksi SIPLO dan pemberian pupuk urine kelinci

\begin{tabular}{ccc}
\hline Perlakuan & \multicolumn{2}{c}{ Hasil (ton/ha) } \\
\hline $\mathrm{I}_{0} \mathrm{U}_{0}$ & 5.80 & $\mathrm{a}$ \\
$\mathrm{I}_{0} \mathrm{U}_{1}$ & 5.85 & $\mathrm{a}$ \\
$\mathrm{I}_{0} \mathrm{U}_{2}$ & 6.56 & $\mathrm{~b}$ \\
$\mathrm{I}_{0} \mathrm{U}_{3}$ & 6.75 & $\mathrm{bc}$ \\
$\mathrm{I}_{1} \mathrm{U}_{0}$ & 6.53 & $\mathrm{~b}$ \\
$\mathrm{I}_{1} \mathrm{U}_{1}$ & 7.14 & $\mathrm{c}$ \\
$\mathrm{I}_{1} \mathrm{U}_{2}$ & 7.80 & $\mathrm{~d}$ \\
$\mathrm{I}_{1} \mathrm{U}_{3}$ & 7.92 & $\mathrm{~d}$ \\
$\mathrm{I}_{2} \mathrm{U}_{0}$ & 7.02 & $\mathrm{bc}$ \\
$\mathrm{I}_{2} \mathrm{U}_{1}$ & 8.22 & $\mathrm{~d}$ \\
$\mathrm{I}_{2} \mathrm{U}_{2}$ & 8.20 & $\mathrm{~d}$ \\
$\mathrm{I}_{2} \mathrm{U}_{3}$ & 8.13 & $\mathrm{~d}$ \\
$\mathrm{I}_{3} \mathrm{U}_{0}$ & 7.03 & $\mathrm{bc}$ \\
$\mathrm{I}_{3} \mathrm{U}_{1}$ & 8.24 & $\mathrm{~d}$ \\
$\mathrm{I}_{3} \mathrm{U}_{2}$ & 8.24 & $\mathrm{~d}$ \\
$\mathrm{I}_{3} \mathrm{U}_{3}$ & 8.81 & $\mathrm{e}$ \\
$\mathrm{BNT}$ & 0.53 & \\
\hline
\end{tabular}

Lahan yang diberi aliran listrik akan mengakibatkan terjadinya pertukaran kation dalam tanah. Saat terjadi pertukaran dimana unsur atau senyawa dalam bentuk ion dan kation terlepas. Fadli dkk. (2018) membuktikan, aplikasi induksi SIPLO dengan interval lima hari sekali memberikan hasil berat ekonomis terbaik pada tanaman selada (Lactuca sativa L.) dibandingkan dengan kontrol.

Tanaman dalam mengambil hara bersamaan saat terjadi difusi air masuk pada jaring tanaman melalui akar lewat xylem dalam bentuk ion atau kation. Kemudian diangkut sampai di daun dan terjadi proses fotosintesis yang mana akan menghasilkan fotosintat. Hasil fotosintat kemudian diangkut ke seluruh bagian tanaman melalui floem ke bagian yang membutuhkan seperti umbi, bunga, daun, batang dan akar (agustina, 2004).

Saat dilakukan induksi kondisi tanah harus basah atau tergenang air. Air merupakan konduktor yang baik untuk penghantar arus listrik. Adanya aliran arus listrik mengakibatkan akan terjadi pertukaran ion dan kation juga pelepasan unsur atau senyawa yang terjerap pada koloid tanah. Unsur pospor sering kali terikat oleh senyawa $\mathrm{Ca}, \mathrm{Fe}$ atau $\mathrm{Al}$, sehingga sulit diserap tanaman. Aplikasi induksi dengan teknik SIPLO dapat meningkatkan KTK tanah dan melepas hara yang terjerap, sehingga bisa tersedia untuk tanaman (Sugiarto et.al., 2013). 
Pemberian urine kelinci pada tanaman bawang putih tunggal memberi kontribusi nutrisi lebih cepat jika diberikan lewat daun. Kelebihan pupuk daun penyerapan hara lewat stomata dan pengaruh pada tanaman cepat terlihat (Handayo, Hadiastono dan Martosudiro, 2013). Urine kelinci mengandung beberapa unsur yang dibutuhkan tanaman. Dilaporkan bahwa urine kelinci mengandung zat pengatur tumbuh seperti auksin, giberellin, nitrogen $2.72 \%$, pospor $1.1 \%$, dan kalium $0.5 \%$ (Balitnak, 2005).

Pemberian aliran arus listrik pada lahan pertanian dapat memperbaiki derajat keasaman tanah. Lahan yang diaplikasi dengan alat induksi SIPLO dapat menetralkan dan meningkatkan $\mathrm{pH}$ tanah. Kondisi keasaman tanah yang netral membuat unsur hara makro dan mikro tersedia cukup sempurna. Kondisi $\mathrm{pH}$ tanah netral seringkali kandungan $\mathrm{P}$ tersedia dalam jumlah banyak tinggi. Unsur hara yang diserap oleh akar tanaman, masuk melalui jaringan angkut berupa ion dan kation. Seperti, unsur pospor diserap oleh tanaman dalam bentuk anion $\mathrm{H}_{2} \mathrm{PO}_{4}{ }^{-}$dan $\mathrm{HPO}_{4}{ }^{2-}$ berasal dari P-organik atau anorganik. $\mathrm{P}$ tersedia akibat kompleks pertukaran ion didominasi kation-kation basa pada kondisi $\mathrm{pH}$ netral. Pertukaran unsur hara cukup efektif dan ketersediaan menjadi optimal pada saat derajat keasaman netral (Prabowo, 2010 ).

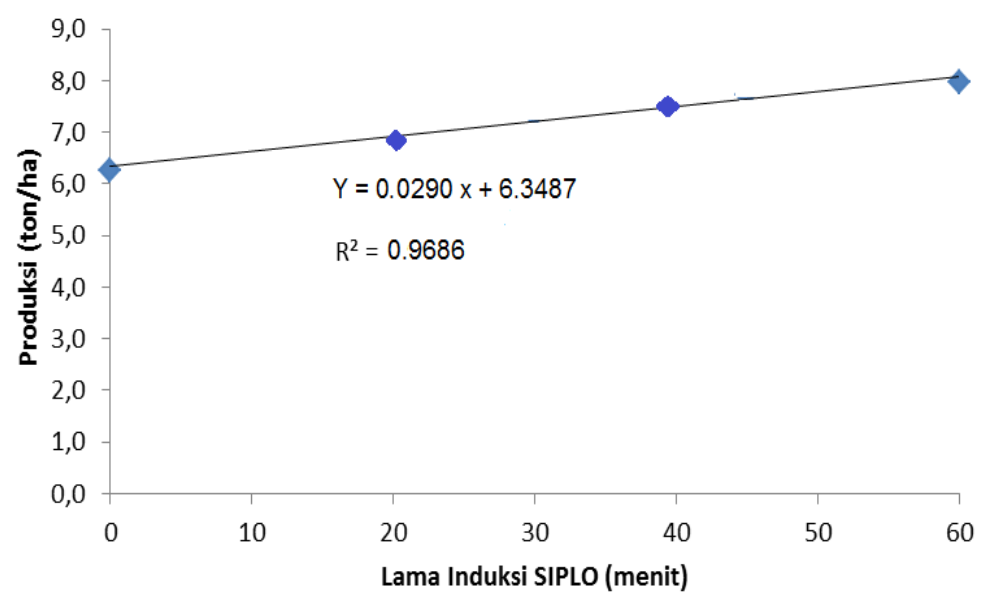

Gambar 1. Pengaruh Lama Induksi SIPLO Terhadap Hasil Bawang Putih Tunggal

Hasil analisis regresi menunjukkan hasil persamaan $y=0.0290 x+6.3487$ dengan $\mathrm{R}^{2}=0,9686$ (Gambar 1.). Keadaan ini menunjukkan bahwa setiap penambahan 1 menit lama induksi SIPLO maka akan menambah hasil bawang putih sebesar 0,0290 ton/ha. Nilai determinasi $(0,9686)$ menunjukkan bahwa pengaruh induksi SIPLO terhadap peningkatan hasil bawang putih sebesar 96,86\%. Peningkatan potensi produksi tanaman bawang putih dapat diakibatkan adanya induksi. Cahya dkk. (2018) menyatakan lama induksi SIPLO 60 menit dan penyemprotan giberelin 500 mg/20.000 liter dapat menaikan hasil buah naga. 


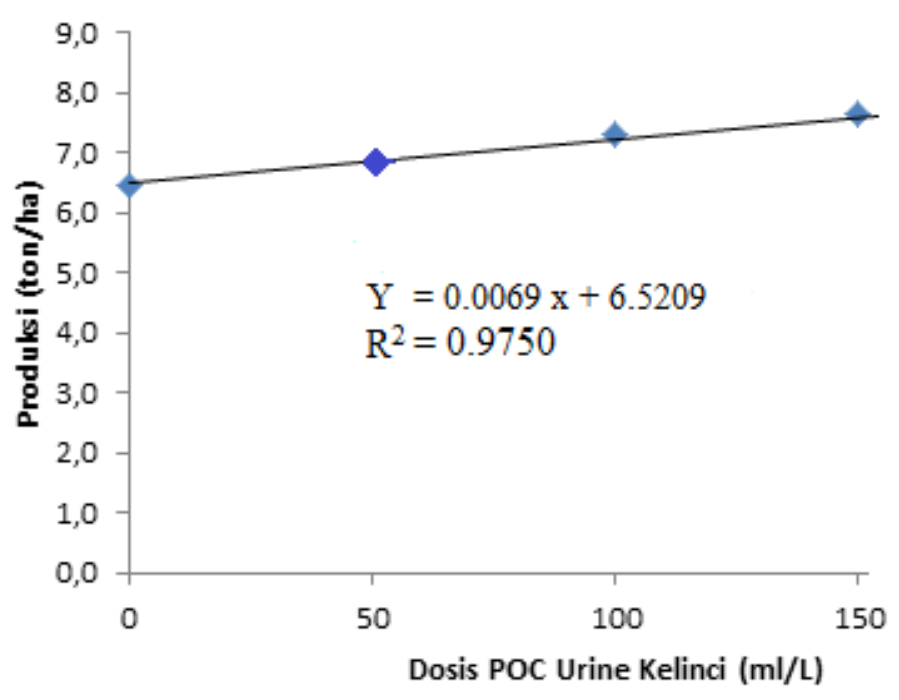

Gambar 2. Pengaruh pemberian pupuk urine kelinci pada produksi tanaman bawang putih tunggal

Pemberian pupuk urine kelinci pada tanaman bawang putih tunggal menunjukkan pengaruh yang baik dalam peningkatan hasil. Dosis $150 \mathrm{ml} / \mathrm{L}$ yang diberikan dengan interval 7 hari sekali terbukti bisa meningkatkan hasil bawang putih. Hasil analisis regresi perlakuan pemberian urine kelinci memperlihatkan hasil persamaan $\mathrm{y}=$ $0.0069 x+6.5209$ dengan $R^{2}=0,9750$ (Gambar 2.). Keadaan ini menunjukkan bahwa setiap penambahan $1 \mathrm{ml} /$ iter pupuk cair urine kelinci dapat meningkatkan produksi bawang putih sebesar 0,0069 ton/ha. Nilai determinasi $(0,9750)$ menunjukkan bahwa pengaruh pemberian pupuk cair urine kelinci terhadap peningkatan produksi bawang putih tunggal sebesar $97,50 \%$. Pemberian pupuk cair melaui daun terbukti lebih bagus untuk jenis tanaman sayuran (Kruniastuti dan Puspitorini, 2018).

Pengaruh pemberian pupuk urine kelinci terhadap kandungan klorofil daun bawang putih tunggal yang ditanam pada dataran medium, tersaji pada Gambar 3. 


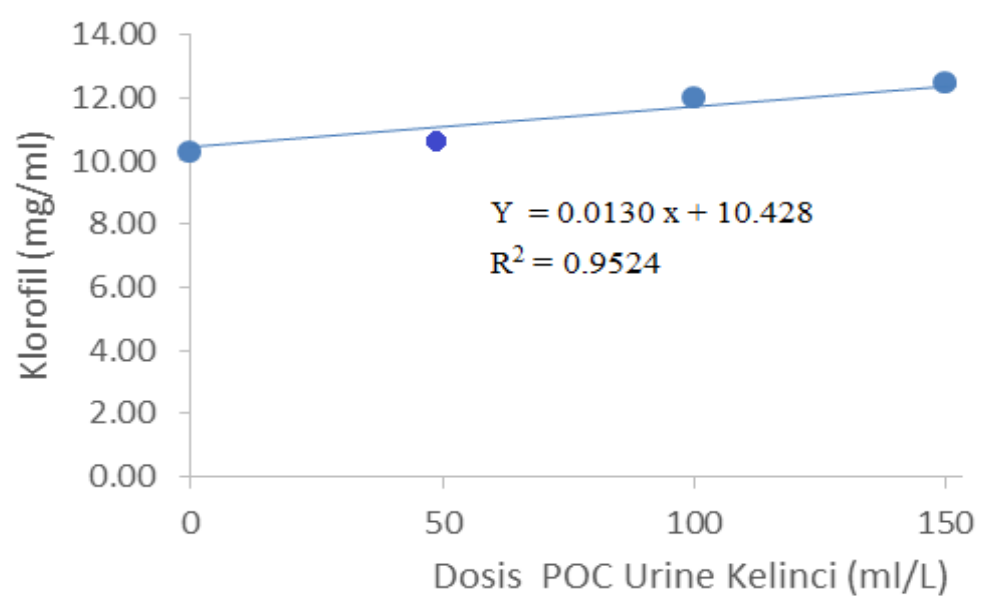

Gambar 3. Pengaruh pemberian pupuk urine kelinci pada klorofil tanaman bawang putih tunggal

Hasil analisis regresi menunjukkan persamaan $y=0.0130 x+10,428$ dengan $R^{2}=$ 0,9524 (Gambar 3.). Keadaan ini menunjukkan setiap penambahan urine kelinci $1 \mathrm{ml}$ akan menambah kandungan klorofil daun bawang putih tunggal 0,0130 mg/ml. Pemberian urine kelinci pada tanaman bawang putih tunggal sangat mempengaruhi peningkatan kandungan klorofil daun yaitu sebesar 95,24\%. Hal ini disebabkan pupuk urine kelinci mengandung beberapa unsur penting yang dibutuhkan tanaman dalam pembentukan klorofil. Kandung hara pada urine kelinci N 4\%; $\mathrm{P}_{2} \mathrm{O}_{5} 2,8 \%$; dan $\mathrm{K}_{2} \mathrm{O} 2 \%$, urine sapi $\mathrm{N} 1,21 \% ; \mathrm{P}_{2} \mathrm{O}_{5}$ 0,65\%; $\mathrm{K}_{2} \mathrm{O}$ 1,6\%, dan urine kambing $\mathrm{N} 1,47 \% ; \mathrm{P}_{2} \mathrm{O}_{5}$ 0,05\%; $\mathrm{K}_{2} \mathrm{O}$ 1,96\%, (Balittanah, 2006).

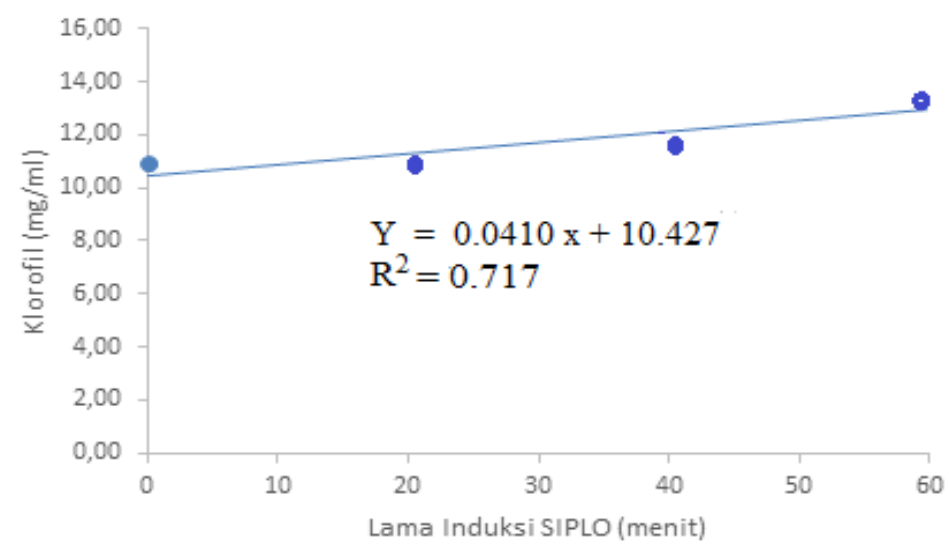

Gambar 4. Pengaruh lama induksi SIPLO terhadap kandungan klorofil tanaman bawang putih tunggal 
Perlakuan induksi SIPLO selama 60 menit memperlihatkan persamaan y $=0.0410$ $x+10,427$ dengan $R^{2}=0,717$ (Gambar 4.). Hal ini menunjukkan, setiap penambahan 1 menit lama induksi SIPLO dapat meningkatkan kandungan klorofil sebanyak 0,0410 $\mathrm{mg} / \mathrm{ml}$. Adapun pengaruh lama induksi SIPLO dalam meningkatkan kadar klorofil daun bawang putih sebesar $71,7 \%$. Hal ini disebabkan lahan diinduksi sehingga hara lebih banyak tersedia dan tanaman bisa menyerap sesuai kebutuhan. Induksi listrik pada lahan pertanian dapat berfungsi menetralkan atau meningkatkan $\mathrm{pH}$, meningkatkan pertukaran kation, dan melepas hara yang terjerap (Sugiarto et.al., 2013).

\section{Kesimpulan}

Perlakuan kombinasi lama Induksi 60 menit dan pemberian POC Urine kelinci 150 $\mathrm{ml} / \mathrm{L}$ dapat meningkatkan hasil bawang putih tunggal sebanyak 8,81 ton/ha dengan peningkatan $51,80 \%$ dibanding kontrol. Secara terpisah aplikasi induksi SIPLO selama 60 menit diperoleh kandungan klorofil daun $12,887 \mathrm{mg} / \mathrm{ml}$ dan pemberian urine kelinci konsentrasi $150 \mathrm{ml} / \mathrm{L}$ didapat $12,378 \mathrm{mg} / \mathrm{ml}$.

\section{Daftar Pustaka}

Agustina. Nutrisi Tanaman. 2004.Rineka Cipta. Jakarta. 66 hal.

Arfarita, N., Hidayati, N., Rosyidah, A., Machfudz, M. and Higuchi, T. 2016. Exploration of indigenous soil bacteria producing- exo polysaccharides for stabilizing of aggregates land potential as biofertilizer. Journal of Degraded and Mining Lands Management 4(1):697-702.

Balitnak di Ciawi, Kabupaten Bogor, pada 2005, Riset Penelitian Ternak, Bogor, Jabar. Balai Besar Litbang Sumberdaya Lahan Pertanian. 2010. Peranan Unsur Hara $N, P, K$ dalam Proses Metabolisme Tanaman Padi. Badan Penelitian dan Pengembangan Pertanian. Bogor. 22 hal.

Balittanah. 2006. Pupuk Organik dan Pupuk Hayati (Organic Fertilizer And Biofertilizer). Balai Besar Litbang Sumberdaya Lahan Pertanian Badan Penelitian dan Pengembangan Pertanian. Bogor.

Cahya, D., Sugiarto, dan S. Muslikah. 2018. Upaya peningkatan produksi buah naga (Hylocereus polyrhizus) dengan aplikasi pemberian giberelin dan lama induksi SIPLO. Jurnal Folium. 2 (1): 1- 9. EISSN 2599-3070.

Fadli, M., Mardiyani S. A. dan Sugiarto. 2018. Aplikasi Teknik Sistem Intensifikasi Potensi Lokal (SIPLO) dan $\mathrm{CaCl}_{2}$ Terhadap Kualitas dan Hasil Produksi Tanaman Selada (Lactuca sativa L.). Jurnal Folium. Vol. 1 (2): 66-78. EISSN 2599-3070.

Handayo, R.,T. Hadiastono dan Martosudiro. M. 2013. Pengaruh Pemberian Pupuk Daun Cair Terhadap Intensitas Serangan Tobacco Mosaic Virus (Tmv), Pertumbuhan dan Produksi Tanaman Tembakau (Nicotiana Tabacum L.).Jurnal HPT 1(2):28- 36.

Kleijn, D., Kohler, F., Baldi, A., Batary, P., Concepcion, E.D., Clough, Y., Diaz, M., Gabriel, D., Holzschuh, A., Knop, E., Kovacs, A., Marshall, E.J.P., Tscharnkte , T., Vershulst, J., 2009. On the relationship between formland biodiversity and landuse internsity in Europe. Proc. R. Soc. B 276,903-909. 
Kurniastuti T. dan Puspito R. 2018. Pengaruh Pemberian Pupuk Pelengkap Cair Pada Media Berbeda Terhadap Pertumbuhan Dan Hasil Tanaman Selada (Lactuca Sativa L.) Varietas Green Rapid. Jurnal Biologi \& Pembelajarannya, Vol.5, No.1, April 2018, pp. 32-43 e-ISSN: 2406 - 8659

Prabowo, R. (2010). Kebijakan Pemerintah Dalam Mewujudkan Ketahanan Pangan Di Indonesia. Jurnal mediagro . 6(2): $62-73$

Shang, J.Q. and Masterson, KL., 2000. "An electrokinetic testing apparatus for undisturbed/ remouded soils under in-situ stress condition". Geotechnical Testing Journal. GTJODJ, Vol. 23, No. 2, p. 215-224.

Sugiarto, Rudi Sulistiono, Sudiarso, dan Soemarno. 2013. Local Potential Intensification System (SIPLO) the Sustainable Management of Soil Organic Potatoes. International Journal Of Engineering And Science.Vol.2, Issue 9 (April 2013), 51-57 